\title{
molecules
}

ISSN 1420-3049

www.mdpi.com/journal/molecules

Article

\section{Use of Titanium Dioxide Photocatalysis on the Remediation of Model Textile Wastewaters Containing Azo Dyes}

\section{Enrico Mendes Saggioro ${ }^{1, *}$, Anabela Sousa Oliveira ${ }^{2,3, *}$, Thelma Pavesi ${ }^{1}$, Cátia Gil Maia ${ }^{3}$, Luis Filipe Vieira Ferreira ${ }^{2}$ and Josino Costa Moreira ${ }^{1}$}

1 Centro de Estudos da Saúde do Trabalhador e Ecologia Humana Escola Nacional de Saúde Pública - Fundação Oswaldo Cruz, Av. Leopoldo Bulhões, 1480, Rio de Janeiro, 21041-210 RJ, Brazil; E-Mails: thelma@fiocruz.br (T.P.); josinocm@fiocruz.br (J.C.M.)

2 CQFM - Centro de Química-Física Molecular and IN - Instituto de Nanociencias e Nanotecnologia, Complexo Interdisciplinar, Instituto Superior Técnico, Universidade Técnica de Lisboa, Av. Rovisco Pais 1049-001, Lisboa, Portugal; E-Mail: LuisFilipeVF@ist.utl.pt (L.F.V.F.)

3 C3i - Centro Interdisciplinar de Investigação e Inovação, Escola Superior de Tecnologia e Gestão, Instituto Politécnico de Portalegre, Lugar da Abadessa Apartado 148 - 7301901 Portalegre, Portugal; E-Mail: catiagmaia@sapo.pt (C.G.M.)

* Authors to whom correspondence should be addressed; E-Mail: saggi_br@hotmail.com (E.M.S.); asoliveira@estgp.pt (A.S.O.); Tel.: +55-21-8880-5568 (E.M.S.); +55-21-2598-2967 (A.S.O.).

Received: 16 October 2011; in revised form: 17 November 2011 / Accepted: 21 November 2011 / Published: 14 December 2011

\begin{abstract}
The photocatalytic degradation of two commercial textile azo dyes, namely C.I Reactive Black 5 and C.I Reactive Red 239, has been studied. $\mathrm{TiO}_{2}$ P25 Degussa was used as catalyst and photodegradation was carried out in aqueous solution under artificial irradiation with a $125 \mathrm{~W}$ mercury vapor lamp. The effects of the amount of $\mathrm{TiO}_{2}$ used, UV-light irradiation time, $\mathrm{pH}$ of the solution under treatment, initial concentration of the azo dye and addition of different concentrations of hydrogen peroxide were investigated. The effect of the simultaneous photodegradation of the two azo dyes was also investigated and we observed that the degradation rates achieved in mono and bi-component systems were identical. The repeatability of photocatalytic activity of the photocatalyst was also tested. After five cycles of $\mathrm{TiO}_{2}$ reuse the rate of colour lost was still $77 \%$ of the initial rate. The degradation was followed monitoring the change of azo dye concentration by UV-Vis spectroscopy. Results show that the use of an efficient photocatalyst and the
\end{abstract}


adequate selection of optimal operational parameters may easily lead to a complete decolorization of the aqueous solutions of both azo dyes.

Keywords: photocatalytic degradation; semiconductor; photocatalysis; azo dyes; $\mathrm{TiO}_{2}$; $\mathrm{TiO}_{2}$ reuse

\section{Introduction}

Dyes are an important source of environmental contamination. Textile wastewaters contain usually a considerable amount of unfixed dyes, many of which are azo dyes [1]. It is estimated that fifteen percent of the total World dye production is lost during dyeing process and it is released in textile effluents [2]. The colours produced by minute amounts of dyes accidentally released in water during dying processes are considered to pose serious problems, because they have considerable environmental effects on the water and make them visually unpleasant [3]. Moreover, environmental pollution by organic dyes also sets a severe ecological problem, which is increased by the fact that most of them are often toxic to microorganisms and a have long degradation times in the environment [4].

The number of dyes currently used in textile industry is about 100.000 , with over $7 \times 10^{5}$ tons of dye-stuffs being produced annually. Among these dyes, the azo dyes constitute the largest and the most important class of commercial dyes $[5,6]$. Those dyes, which typically have the chromophoric $-\mathrm{N}=\mathrm{N}$ group unit in their molecular structure [7] makes up to $60-70 \%$ of all textile dyestuffs produced.

Azo dyes are known to be largely non-biodegradable under aerobic conditions and their stability is proportional to the structural complexity of their molecular structures $[7,8]$. In order to overcome this problem, azo dyes can be degraded under anaerobic conditions, but causing in this case potentially hazardous and carcinogenic aromatic amines [8,9]. It is well known that azo dye structure when incorporated into the body is split by liver enzymes and intestinal flora into the corresponding aromatic amines, which can cause cancer in humans [7]. Dyes are synthesized to be resistant to fading upon exposure to light, washing and many chemicals [5]. Consequently, traditional wastewater treatment methods such as flocculation, adsorption and biological degradation are usually ineffective [4].

In recent years Advanced Oxidation Processes (AOPs) using titanium dioxide $\left(\mathrm{TiO}_{2}\right)$ have been effectively used to detoxify recalcitrant pollutants present in industrial wastewater [9-12]. $\mathrm{TiO}_{2}$ have singular characteristics that made it an extremely attractive photocatalyst: high photochemical reactivity, high photocatalytic activity, low cost, stability in aquatic systems and low environmental toxicity $[13,14]$. When a semiconductor such as $\mathrm{TiO}_{2}$ absorbs a photon with energy equal to or greater than its band gap width $(3.2 \mathrm{eV})$, an electron may be promoted from the valence band to the conduction band $\left(\mathrm{e}_{\mathrm{cb}}^{-}\right)$leaving behind an electron vacancy in the valence band $\left(\mathrm{h}^{+}{ }_{\mathrm{vb}}\right)$ [15]. The holes at the $\mathrm{TiO}_{2}$ valence band, having an oxidation potential of $+2.6 \mathrm{~V}$ can oxidize water or hydroxide to produce hydroxyl radicals. The hydroxyl radical is a powerful oxidizing agent and enables a nonspecific attack on organic compounds; under favorable conditions the final photoproducts are $\mathrm{H}_{2} \mathrm{O}$, $\mathrm{CO}_{2}$ and inorganic anions. The general detailed mechanism of dye degradation upon irradiation is described by Equations $1-6[4,15]$ : 


$$
\begin{aligned}
& \text { Dye }+h v \rightarrow \text { Dye* } \\
& \text { Dye } *+\mathrm{TiO}_{2} \rightarrow \mathrm{Dye}^{+}+\mathrm{TiO}_{2}(\mathrm{e}) \\
& \mathrm{TiO}_{2}(\mathrm{e})+\mathrm{O}_{2} \rightarrow \mathrm{TiO}_{2}+\mathrm{O}_{2}^{\cdot-} \\
& \mathrm{O}_{2}^{--}+\mathrm{TiO}_{2}(\mathrm{e})+2 \mathrm{H}^{+} \rightarrow \mathrm{H}_{2} \mathrm{O}_{2} \\
& \mathrm{H}_{2} \mathrm{O}_{2}+\mathrm{TiO}_{2}(\mathrm{e}) \rightarrow{ }^{\circ} \mathrm{OH}+\mathrm{OH}^{-} \\
& \text {Dye }{ }^{+}+\mathrm{O}_{2}\left(\text { or } \mathrm{O}_{2}{ }^{--} \text {or }{ }^{\bullet} \mathrm{OH}\right) \rightarrow \text { peroxylated or hydroxylated intermediates } \\
& \rightarrow \text { degraded or mineralized products }
\end{aligned}
$$

Nowadays it is well known that $\mathrm{TiO}_{2}$ is one of the most suitable semiconductors for photocatalysis and has been applied into various photocatalytic reactions [16-26]. The aim of the present work was to investigate the influence of various parameters on the photocatalytic degradation of two textile azo dyes, namely C.I Reactive Black 5 and C.I Reactive Red 239, by UV-light irradiation in the presence of $\mathrm{TiO}_{2}$. In this paper, we will also examine the effects of the amount of $\mathrm{TiO}_{2}$ used, $\mathrm{pH}$, initial concentration of the dyes, the use of an electron acceptor such as hydrogen peroxide and test the efficiency of $\mathrm{TiO}_{2}$ recycling and reuse.

\section{Results and Discussion}

\subsection{Effect of $\mathrm{TiO}_{2}$ Photocatalyst Concentration}

The photocatalytic degradation of the two azo dyes $\left(30 \mathrm{mg} \cdot \mathrm{L}^{-1}\right)$ with different $\mathrm{TiO}_{2}$ amounts was studied according to the described below in Section 3.3 and the obtained results are shown in Figure 1. The efficiency of photocatalytic degradation of both dyes clearly increased with the increase of the amount of photocatalyst. The concentration of $1 \mathrm{~g} \cdot \mathrm{L}^{-1}$ of $\mathrm{TiO}_{2}$ degraded around $90 \%$ of both dyes in about $45 \mathrm{~min}$ and $99 \%$ of degradation was attained after $120 \mathrm{~min}$. However, the concentration of $0.1 \mathrm{~g} \cdot \mathrm{L}^{-1}$ of $\mathrm{TiO}_{2}$ in the end of $120 \mathrm{~min}$ of irradiation yielded a similar degradation to that of the highest concentration of $\mathrm{TiO}_{2}$ used. This can be rationalized in terms of availability of active sites on the $\mathrm{TiO}_{2}$ surface and of the light penetration of photoactivating light into the dye- $\mathrm{TiO}_{2}$ suspension; in fact in the solutions of both azo dyes, containing $1 \mathrm{~g} \cdot \mathrm{L}^{-1}$ of $\mathrm{TiO}_{2}$ in suspension the light penetration depth is considerably smaller than in those containing only $0.1 \mathrm{~g} \cdot \mathrm{L}^{-1}$ of $\mathrm{TiO}_{2}$ and so the effect of the increase on the amount of photocatalyst becomes reduced. For the two azo dyes studied in this work the treatment with $\mathrm{TiO}_{2}$ under artificial irradiation of a $125 \mathrm{~W}$ mercury vapor lamp was an extremely efficient photodegradation method, since after 2 hours all dyes showed substantial colour losses.

The photodegradation is mostly promoted by titanium dioxide since we observed that direct photolysis, in the two hours irradiation period, is only responsible for the degradation of 0 to $6 \%$ of both of these azo dyes. Therefore, under irradiation, only the molecules adsorbed on the surface of $\mathrm{TiO}_{2}$ can be degraded. When the amount of catalyst used on the photocatalytic degradation is very high the turbidity of the suspension strongly inhibits further light penetration in the photoreactor [26,27]. This limit on $\mathrm{TiO}_{2}$ amount to be used depends on the geometry and working conditions of the photoreactor which should enable that all the photocatalyst particles present on the entire exposed surface are fully illuminated [28]. In this way, for each system to be remediated thought this method, 
the optimum amount of $\mathrm{TiO}_{2}$ has to be determined in order to avoid the use of unnecessary catalyst in excess and also to ensure the total absorption of the irradiating photons in order to achieve an efficient photoremediation.

Figure 1. Effect of $\mathrm{TiO}_{2}$ amount on the complete degradation of $30 \mathrm{mg} \cdot \mathrm{L}^{-1}$.I. Reactive Red $239\left(\longrightarrow\right.$ and C.I Reactive Black 5 (-----) dyes in $120 \mathrm{~min}$ of irradiation with $2,60 \mathrm{~mW} / \mathrm{cm}^{2}$ of irradiation power by a $125 \mathrm{~W}$ mercury lamp.

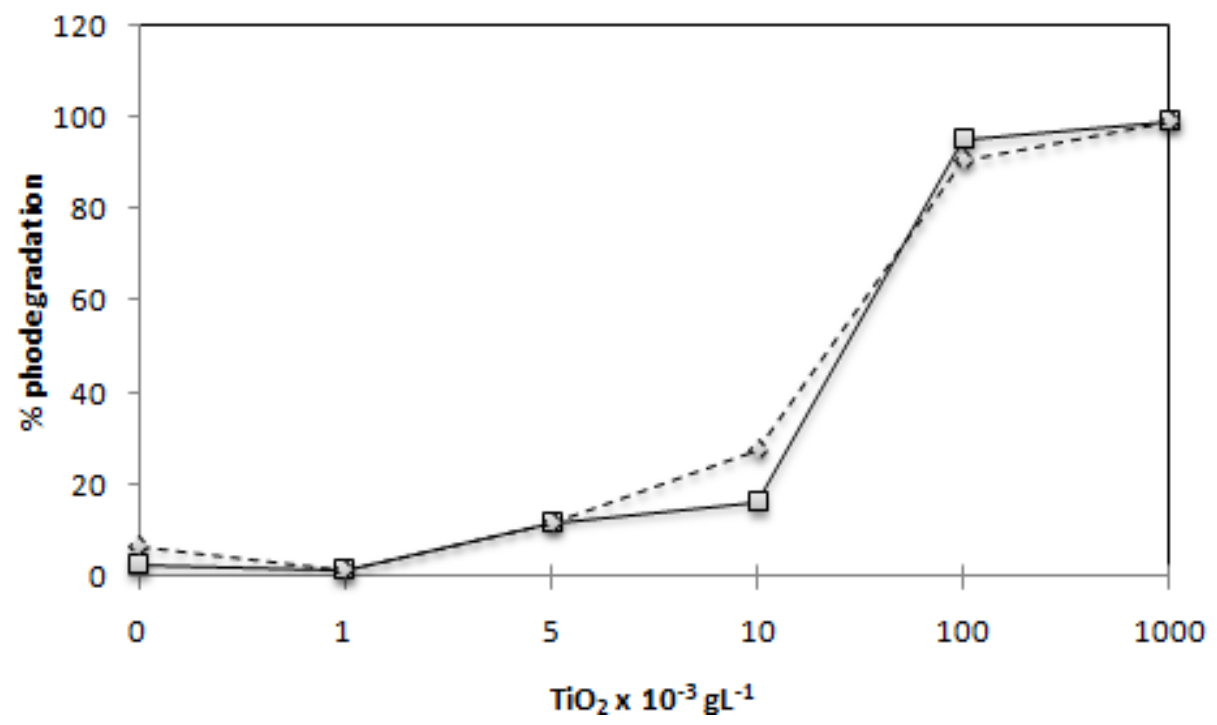

\subsection{Effect of UV-Irradiation Time}

Figures 2 and 3 show the effect of UV-light irradiation time on the photocatalytic degradation of C.I. Reactive Black 5 and C.I. Reactive Red 239 with the two most efficient added amounts of $\mathrm{TiO}_{2}$, $0.1 \mathrm{~g} \cdot \mathrm{L}^{-1}$ and $1 \mathrm{~g} \cdot \mathrm{L}^{-1}$, respectively. In the presence of $1 \mathrm{~g} \cdot \mathrm{L}^{-1}$ of $\mathrm{TiO}_{2}$ and $\mathrm{UV}$-light, 75 and $79 \%$ of the two azo dyes were degraded, respectively, after an irradiation time of $30 \mathrm{~min}$. It is also evident that for both of them the percentage of decolorization and photodegradation increases with increasing irradiation time. As expected the concentration of $1 \mathrm{~g} \cdot \mathrm{L}^{-1}$ of $\mathrm{TiO}_{2}$ promoted the highest percentage of degradation for the two dyes. This concentration degraded 90 to $93 \%$ in 45 min of both azo dyes. The rate of degradation became slower after 45 minutes. By the end of two hours up to 90 to $95 \%$ of the azo dyes were degraded by $0.1 \mathrm{~g} \cdot \mathrm{L}^{-1}$ of catalyst. However, $1 \mathrm{~g} \cdot \mathrm{L}^{-1}$ degraded up to 93 to $99 \%$ of dyes for the longest irradiation times.

The slow kinetics of azo dyes degradation after a long time of irradiation arises from the difficulty in converting the $\mathrm{N}$ atoms of the dyes into oxidized nitrogen compounds, since aliphatic chain interaction with hydroxyl radicals is small and these radicals are short lived [29]. The quick lost of colour of both azo dyes solutions was associated with cleavage of the azo linkage in dyes molecules. The nitrogen to nitrogen double bonds $(-\mathrm{N}=\mathrm{N}-)$ are characteristic of azo dyes molecules and theirs colours are determined by azo bonds. Azo bonds are the most active bonds in azo dye molecules and can be easily oxidized either by positive holes or hydroxyl radicals [30,31]. 
Figure 2. Effect of UV-Irradiation time on the degradation of $30 \mathrm{mg} \cdot \mathrm{L}^{-1}$ of the azo dyes C.I. Reactive Red $239(-\bullet)$ and C.I Reactive Black $5(-\square-)$ with $0.1 \mathrm{~g} \cdot \mathrm{L}^{-1}$ of $\mathrm{TiO}_{2}$ and $2.60 \mathrm{~mW} / \mathrm{cm}^{2}$ of irradiation power by a $125 \mathrm{~W}$ mercury lamp.

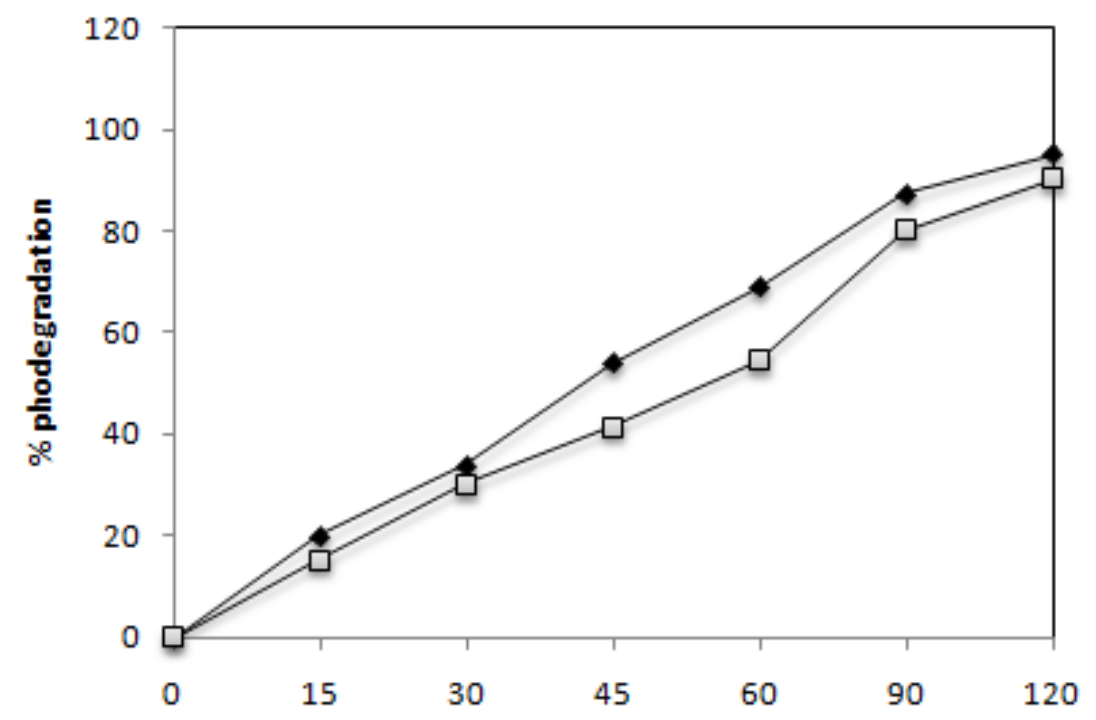

Figure 3. Effect of UV-Irradiation time on the degradation of $30 \mathrm{mg} \cdot \mathrm{L}^{-1}$ of the azo dyes C.I. Reactive Red $239(\neg-)$ and C.I Reactive Black $5(\diamond-)$ with $1 \mathrm{~g} \cdot \mathrm{L}^{-1}$ of $\mathrm{TiO}_{2}$ and $2.60 \mathrm{~mW} / \mathrm{cm}^{2}$ of irradiation power by a $125 \mathrm{~W}$ mercury lamp.

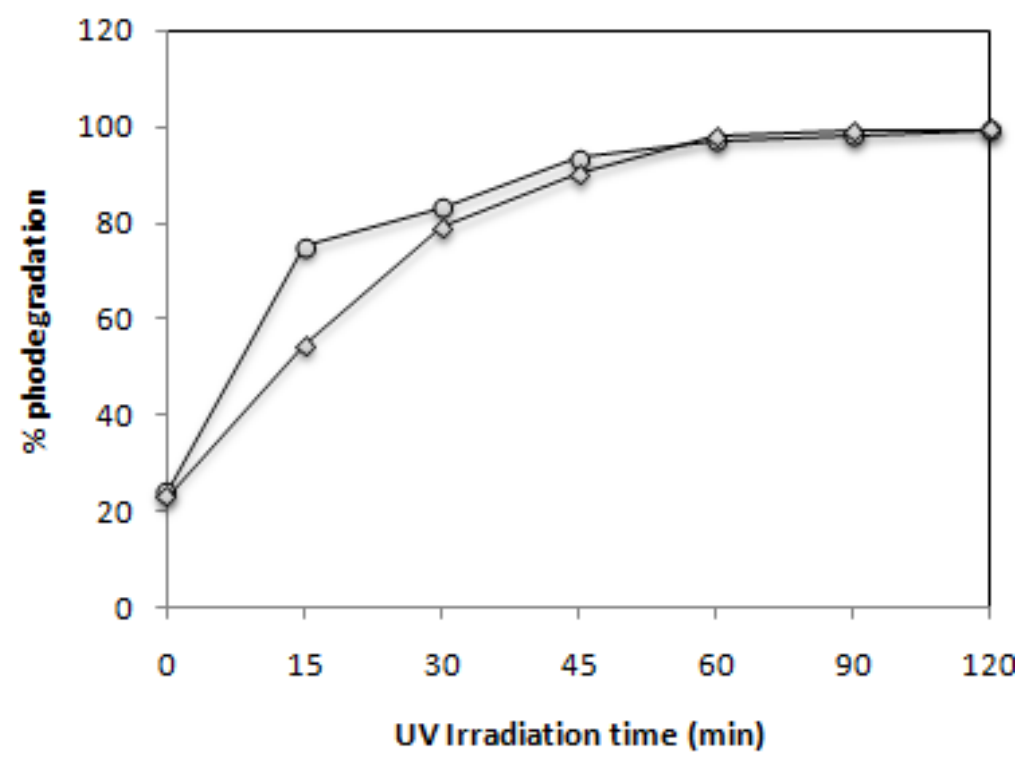

The cleavage of double bonds leads to the decolourization of the dye. The UV-Vis spectra measured during photodegradation of the two commercial azo dyes are shown in Figure 4. Before irradiation, C.I Reactive Black 5 exhibits peaks at 615,397, 312 and $231 \mathrm{~nm}$ and C.I. Reactive Red 239 exhibits peaks at 540, 328, 289 and $215 \mathrm{~nm}$. The visible spectrum peaks are due to chromophoric group absorptions, whereas the bands observed in the UV region can be assigned to the aromatic rings present in both azo dye structures, as can be observe in Figure 10 [32,33]. Figure 4 shows for both dyes the fast decolorization observed and also a significant degradation of their aromatic structures. 
Figure 4. Photocatalytic degradation under $125 \mathrm{~W}$ mercury-vapor lamp irradiation with $0.1 \mathrm{~g} \cdot \mathrm{L}^{-1}$ of $\mathrm{TiO}_{2}$ followed by UV-Vis spectrophotometry from 200 to $900 \mathrm{~nm}$ for $30 \mathrm{mg} \cdot \mathrm{L}^{-1}$ of (a) C.I Reactive Black 5 and (b) C.I Reactive Red 239.

(a)

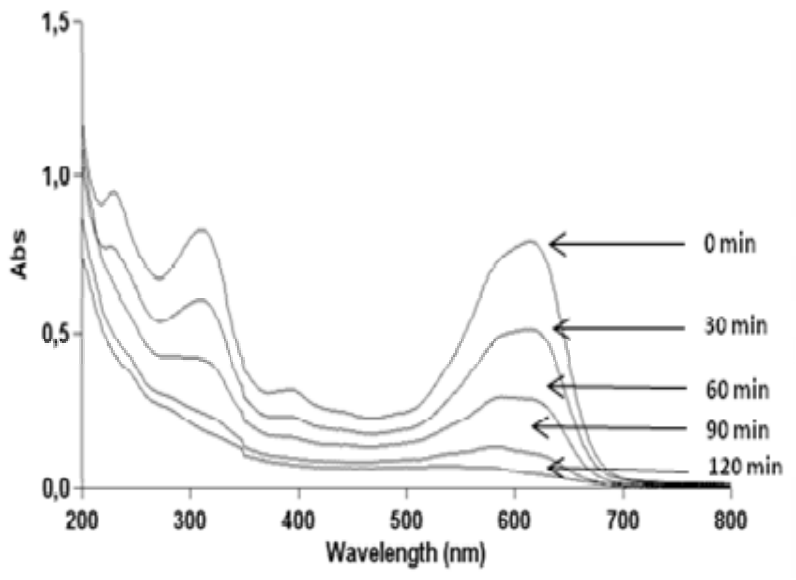

(b)

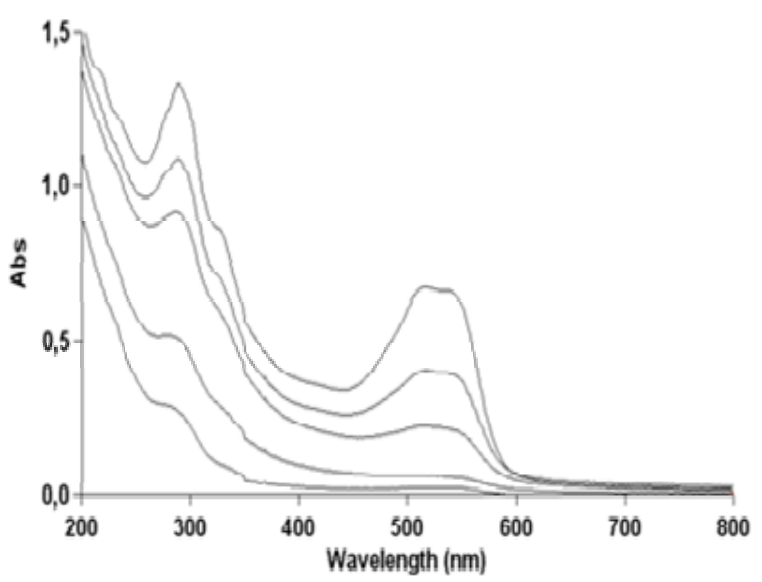

\subsection{Effect of $p H$}

$\mathrm{pH}$ is an important parameter for reactions taking place on the surface of a particulate, as is the case of $\mathrm{TiO}_{2}$ photocatalysis. $\mathrm{pH}$ variation can in fact influence the adsorption of dye molecules onto the $\mathrm{TiO}_{2}$ surfaces [34]. The effect of solution $\mathrm{pH}$ was studied in the range of 2 to 10 for the optimized catalyst amounts (i.e., $0.1 \mathrm{gL}^{-1}$ ) and UV-irradiation times (up to $120 \mathrm{~min}$ ) for the azo dyes under study. Figure 5 shows the variation on the efficiency photocatalytic degradation of C.I Reactive Black 5 at different $\mathrm{pH}$ values. Photodegradation was higher in acidic media ( $\mathrm{pH} 2$ to 4), with degradation rates of 95 and $93 \%$, respectively. Up to a $\mathrm{pH}$ value of 7, the dye degradation efficiency decreased to $77 \%$. Above $\mathrm{pH} 7$, the degradation continued to decrease to about $70 \%$ at $\mathrm{pH} 10$.

Figure 5. $\mathrm{TiO}_{2}\left(0.1 \mathrm{~g} \cdot \mathrm{L}^{-1}\right)$ photodegradation efficiency of $30 \mathrm{mgL} \mathrm{L}^{-1}$ C.I Reactive Black 5 at different $\mathrm{pH}$ values.

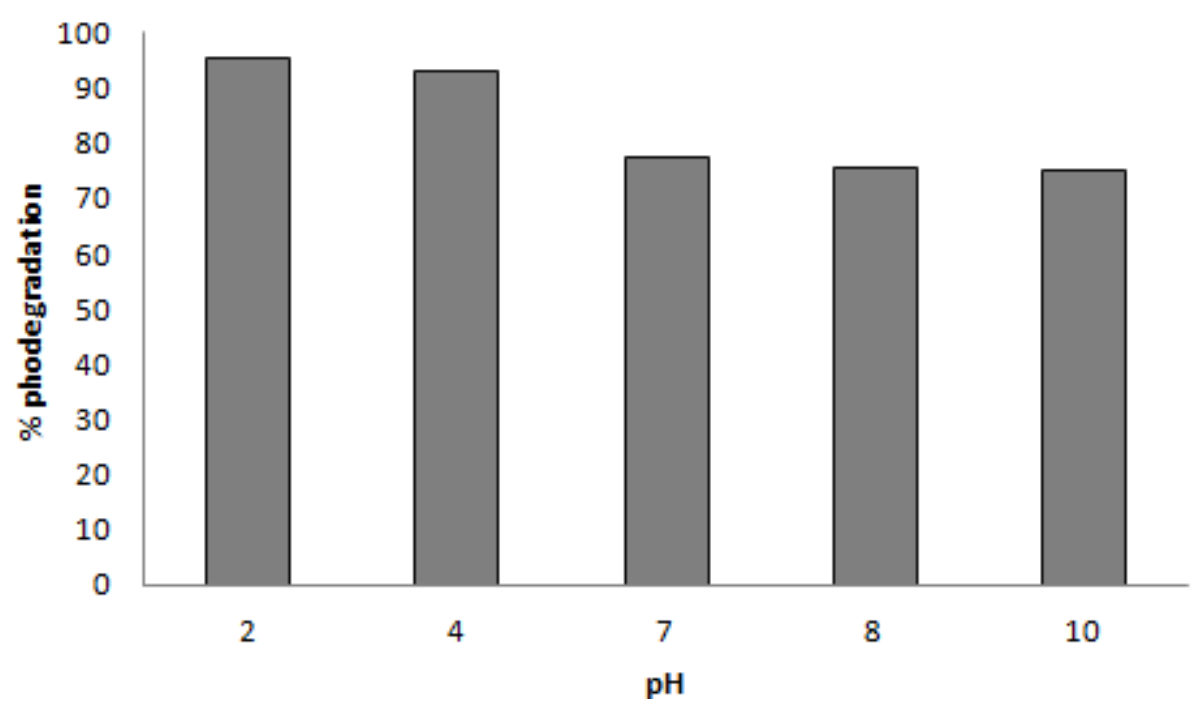

This catalyst behavior can be explained by $\mathrm{TiO}_{2}$ surface charge density. The point of zero charge (pzc) of the $\mathrm{TiO}_{2}$ (Degussa P25) is at $\mathrm{pH}$ 6.8. In acid media $(\mathrm{pH} \leq 6.8)$ the $\mathrm{TiO}_{2}$ surface is positively 
charged, whereas under alkaline conditions $(\mathrm{pH} \geq 6.8)$ it is negatively charged $[25,35]$. Considering the structure of C.I Reactive Black 5 (Figure 10a), a positive charge excess in the $\mathrm{TiO}_{2}$ surface promotes a strong interaction with $\mathrm{SO}_{3}{ }^{-}$groups of the dye (Figure 6a). A negative charge excess promotes the repulsion of the dye by the titanium surface, diminishing the catalytic activity of this semiconductor (Figure 6b). These results suggest that the influence of the initial $\mathrm{pH}$ of the solution on photocatalysis kinetics is due to the amount of the dye adsorbed on $\mathrm{TiO}_{2}$ [23,34]. This hypothesis agrees with a reaction occurring at $\mathrm{TiO}_{2}$ surface and not in the solution, close to the surface.

Figure 6. Schematic interaction model of C.I Reactive Black 5 and $\mathrm{TiO}_{2}$ : (a) acid sites and (b) basic sites.

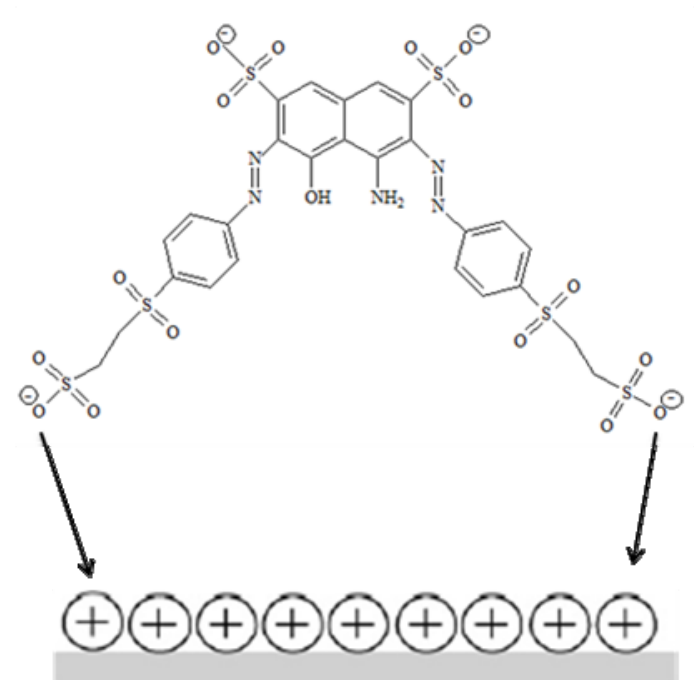

(a)

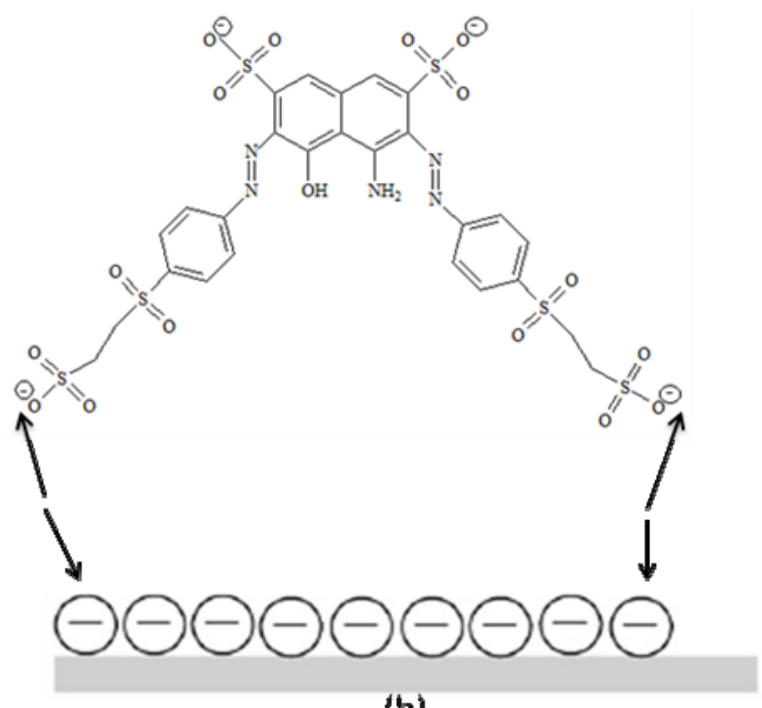

(b)

\subsection{Recycling of $\mathrm{TiO}_{2}$}

One of today's main industrial wastewater treatment strategies is focused on the development of green technologies and management practices for environmental benefit. Then, $\mathrm{TiO}_{2}$ recycling can be foreseen as a good practice for sustainable wastewater treatment. Consequently, it is necessary to demonstrate whether, after a photocatalytic treatment, the catalyst can be reused. The $\mathrm{TiO}_{2}$ catalyst was used and recycled for consecutive reuse on the C.I. Reactive Red 239 degradation; the process was repeated up to five times. The $\mathrm{TiO}_{2}$ recycling studies were performed with $0.1 \mathrm{~g} \cdot \mathrm{L}^{-1}$ of the catalyst and the efficiency of the photodegradation process was evaluated and compared between the reuse cycles, as shown in Figure 7.

These studies reveled that $\mathrm{TiO}_{2}$ demonstrated good stability after recovery and that catalyst reuse is effective. The first cycle degraded $99 \%$ of the dye after 60 minutes of irradiation. Subsequently, the second and third cycle degraded 96 and 94\% the dye, respectively. After these cycles, the efficiency markedly decreased, as demonstrated in the fourth and fifth cycles, where the rates of degradation felt to 63 and $62 \%$ respectively. However, the rate of degradation is still significant after five times of $\mathrm{TiO}_{2}$ reuse. Agglomeration and sedimentation of the dye around $\mathrm{TiO}_{2}$ particles after each cycle of photocatalytic degradation is a possible cause of the observed decrease on the degradation rate, because each time the photocatalyst is reused new parts of the catalyst surface become unavailable for dye adsorption and thus photon absorption, reducing the efficiency of the catalytic reaction. 
Figure 7. Catalytic yields of $0.1 \mathrm{~g} \cdot \mathrm{L}^{-1}$ of $\mathrm{TiO}_{2}$ as a function of its reuse of $30 \mathrm{mg} \cdot \mathrm{L}^{-1}$ of C.I. Reactive Red 239 photodegradation.

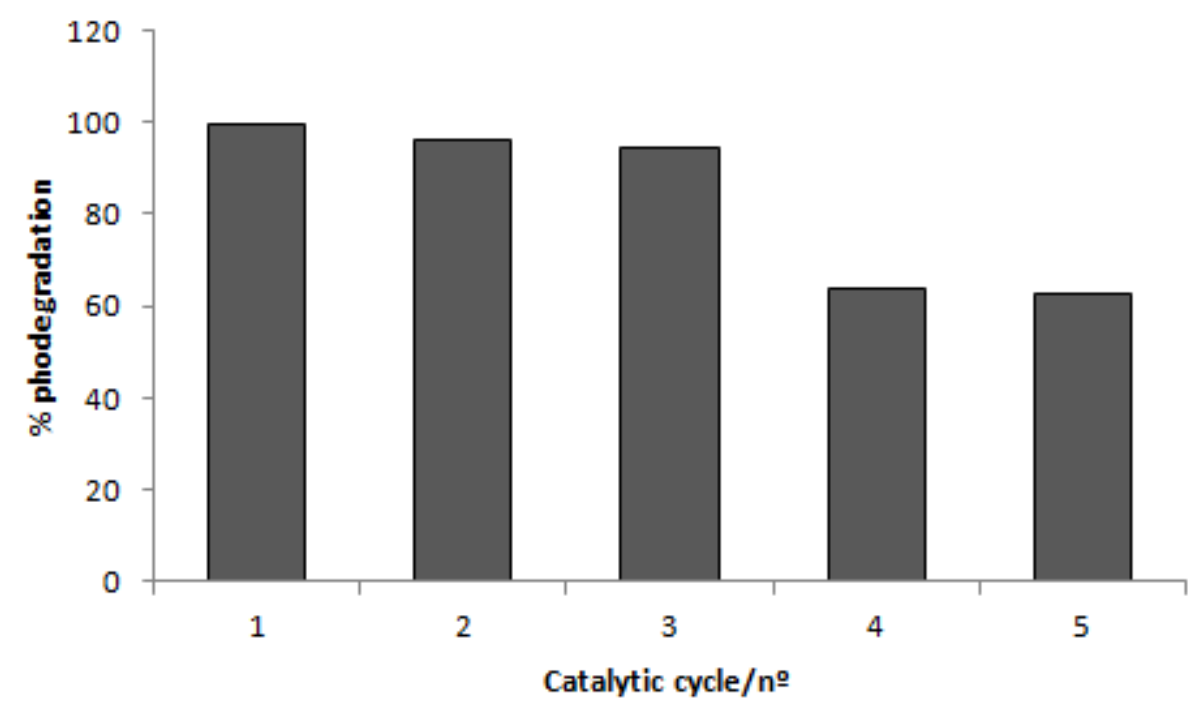

An alternative to regenerate $\mathrm{TiO}_{2}$ after each usage is to apply $\mathrm{H}_{2} \mathrm{O}_{2}$ under UV irradiation [36]. Wang et al. [37] used $\mathrm{TiO}_{2}$ modified by photocatalytic degradation through six successive batches and obtained successively similar rates of degradation, demonstrating that the $\mathrm{H}_{2} \mathrm{O}_{2}$ coated $\mathrm{TiO}_{2}$ have an enhanced photochemical stability for reuse. Xie and Yuan [38] utilized a pure recycled $\mathrm{TiO}_{2}$ in the degradation of an organic dye and observed that the removal ratio kept above $90 \%$ after three times or reuse, and above $77 \%$ after five times of reuse. This ability of titanium dioxide to be reused goes towards green chemistry key principles.

\subsection{Effect of Dye Concentration}

The effect of the initial concentration of C.I Reactive Black 5 and C.I. Reactive Red 239 on the decomposition of the dye under the $125 \mathrm{~W}$ mercury lamp reactor was determined. The obtained results are presented in Figure 8. The results indicate that the decomposition rate of both dyes strongly depends on the initial dye concentration. The efficiency of photodegradation of both dyes decreased with increase of the initial dye concentration.

C.I Reactive Black 5 and C.I. Reactive Red 239 with $30 \mathrm{mg} \cdot \mathrm{L}^{-1}$ of photocatalyst show rates of degradation of 95 and $97 \%$, respectively. On increasing the concentration of the dye until $150 \mathrm{mg} \cdot \mathrm{L}^{-1}$ the photodegradation became very slow, presenting a degradation of only $9 \%$ for C.I. Reactive Red 239 and 10\% for C.I Reactive Black 5. As the initial concentration of the dye increased, more dye molecules were adsorbed on the surface on the catalyst, consequently the generation of hydroxyl radicals was reduced since the active sites were occupied by dyes [24,39,40]. An increase of the initial dye concentration results in an increase of the amount of dye adsorbed on the catalyst surface, affecting the catalytic activity of the photocatalyst $[41,42]$. Moreover the reduction of the light path length as the concentration and deepness of the colour of the solution rises also cannot be neglected. 
Figure 8. Effect of the initial concentration of C.I. Reactive Red $239(-\diamond)$ and C.I Reactive Black $5(-)$ ) dyes on the efficiency attained after $2 \mathrm{~h}$ of irradiation with $0.1 \mathrm{~g} \cdot \mathrm{L}^{-1}$ of $\mathrm{TiO}_{2}$ and $2,60 \mathrm{~mW} / \mathrm{cm}^{2}$ of irradiation power by a $125 \mathrm{~W}$ mercury lamp.

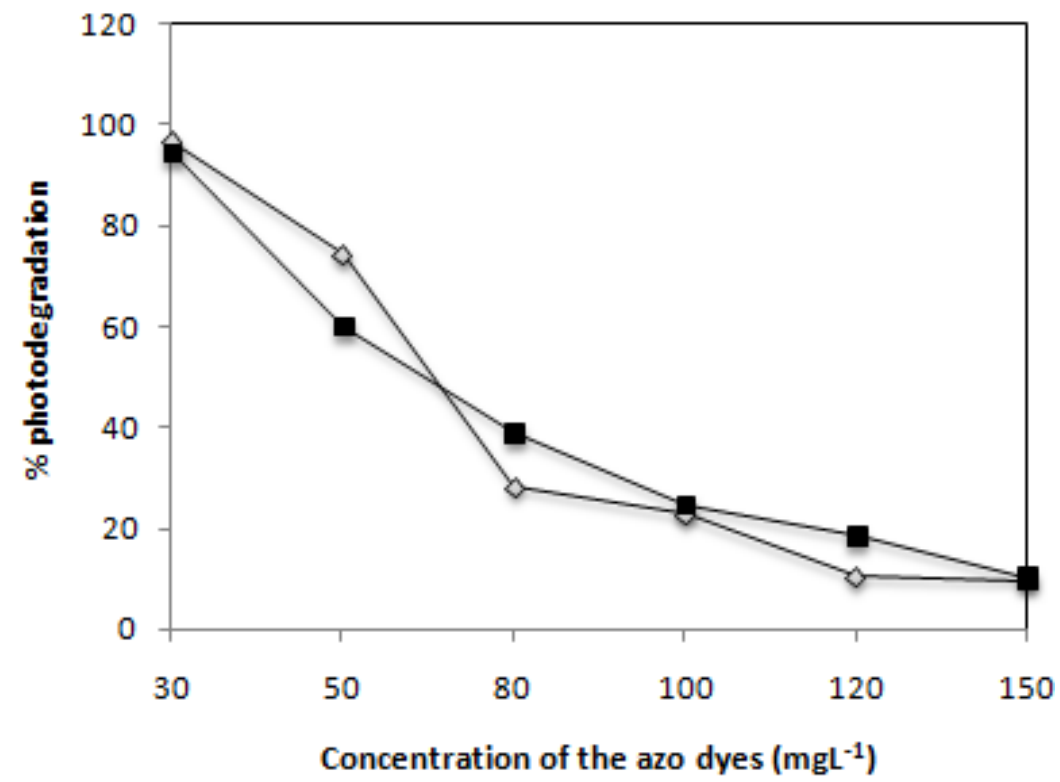

\subsection{Effect of $\mathrm{H}_{2} \mathrm{O}_{2}$}

Since hydroxyl radicals appear to play an important role in the photocatalytic degradation, electron acceptors such as hydrogen peroxide were added to the dye solution. Hydrogen peroxide has been found to enhance the degradation of compounds due to a more efficient generation of hydroxyl radical and inhibition of electron/hole pair recombination. The degradation rates for the C.I Reactive Black 5 and C.I. Reactive Red 239 in presence of $\mathrm{UV} / \mathrm{TiO}_{2} / \mathrm{H}_{2} \mathrm{O}_{2}$ in order to find the optimal $\mathrm{H}_{2} \mathrm{O}_{2}$ concentration to be used are shown in Figure 9. It was observed that the added hydrogen peroxide had a beneficial effect on the degradation of both azo dyes. The maximum reaction rate was observed with $0.3 \times 10^{-2} \mathrm{~mol} \cdot \mathrm{L}^{-1}$ of $\mathrm{H}_{2} \mathrm{O}_{2}$ for both dyes (achieving a $96 \%$ degradation rate in 60 minutes). The two $\mathrm{H}_{2} \mathrm{O}_{2}$ concentrations below the latter $\left(0.6 \times 10^{-2}\right.$ and $\left.0.9 \times 10^{-2} \mathrm{~mol} \cdot \mathrm{L}^{-1}\right)$ produced satisfactory and similar photocatalytic degradation rates (93 and 91\%) for both dyes. At higher concentrations of $\mathrm{H}_{2} \mathrm{O}_{2}$ the degradation efficiency decreased significantly for C.I. Reactive Red 239, with only $25 \%$ of degradation being obtained with the highest concentration of $\mathrm{H}_{2} \mathrm{O}_{2}$ used. For C.I Reactive Black 5 respectively 89 and $82 \%$ of degradation were achieved with $1.2 \times 10^{-2} \mathrm{~mol} \cdot \mathrm{L}^{-1}$ and $3 \times 10^{-2} \mathrm{~mol} \cdot \mathrm{L}^{-1}$ of $\mathrm{H}_{2} \mathrm{O}_{2}$, but the highest concentration of $\mathrm{H}_{2} \mathrm{O}_{2}$ used degraded just $29 \%$.

The electron/hole recombination is a problem in photocatalytic degradation in presence of the $\mathrm{TiO}_{2}$, and then one strategy to inhibit electron-hole pair recombination is to add other electron acceptors to the reaction [43]. When present at a low concentration, hydrogen peroxide enhanced the degradation rate, a fact that could be attributed to a suitable trapping of electrons by hydrogen peroxide thereby preventing the recombination of $\mathrm{e}^{-}$and $\mathrm{h}^{+}$pairs and thus increasing the chances of formation of hydroxyl radicals on the surface of the catalyst [44,45]. However, when the concentration of $\mathrm{H}_{2} \mathrm{O}_{2}$ increases, the electron acceptor reacts with hydroxyl radicals, and acts as scavenger of the 
photoproduced holes. In addition, $\mathrm{H}_{2} \mathrm{O}_{2}$ can modify the $\mathrm{TiO}_{2}$ surface. This fact probably decreases its photocatalytic efficiency [46].

Figure 9. Effect of the presence of hydrogen peroxide on the photodegradation of C.I. Reactive Red $239(\bullet-)$ ) and C.I Reactive Black $5(-\square)$ dyes after 60 min of irradiation with $0.1 \mathrm{~g}-\mathrm{L}^{-1}$ of $\mathrm{TiO}_{2}$ and $2,60 \mathrm{~mW} / \mathrm{cm}^{2}$ of irradiation power by a $125 \mathrm{~W}$ mercury lamp.

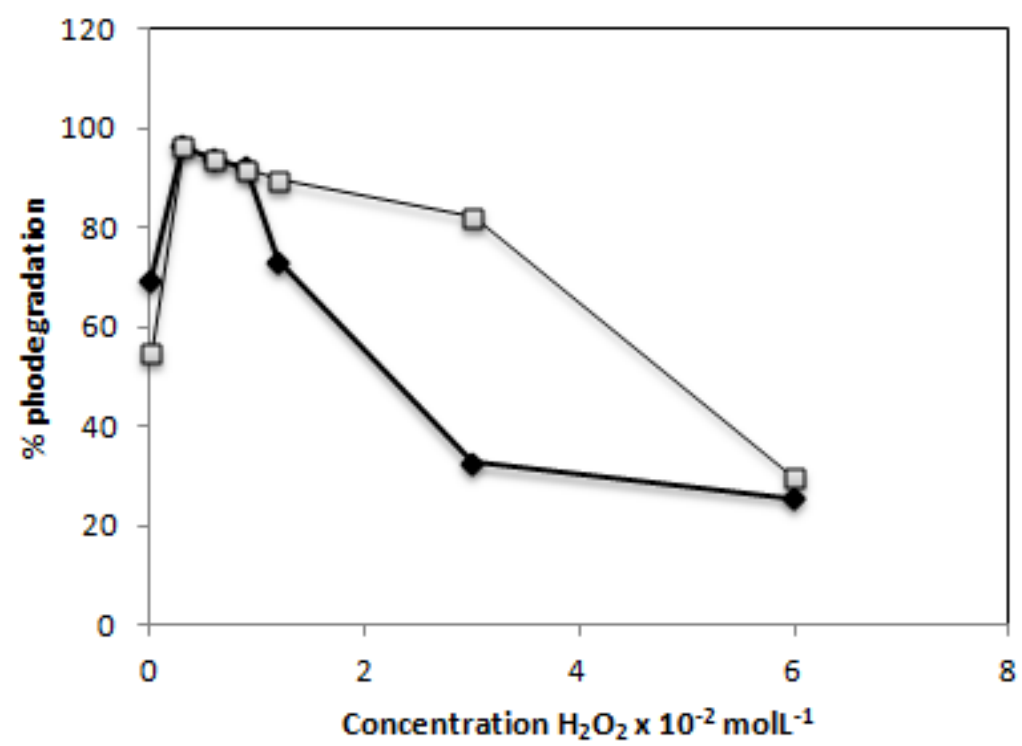

\subsection{Effect of the Mixture of the Two Azo Dyes}

Since in real effluents from dye industries the presence of several dyes in the waters is frequent we decided to test the effect of the simultaneous presence in solution of both azo dyes under study in this work. The obtained results are present below in Figures 10 and 11.

Figure 10. Photocatalytic degradation under $125 \mathrm{~W}$ mercury-vapor lamp irradiation with $0.1 \mathrm{~g} \cdot \mathrm{L}^{-1}$ of $\mathrm{TiO}_{2}$ followed by UV-Vis spectrophotometry from 200 to $900 \mathrm{~nm}$ for a $30 \mathrm{mg} \cdot \mathrm{L}^{-1}$ mixture of C.I Reactive Black 5 and C.I Reactive Red 239.

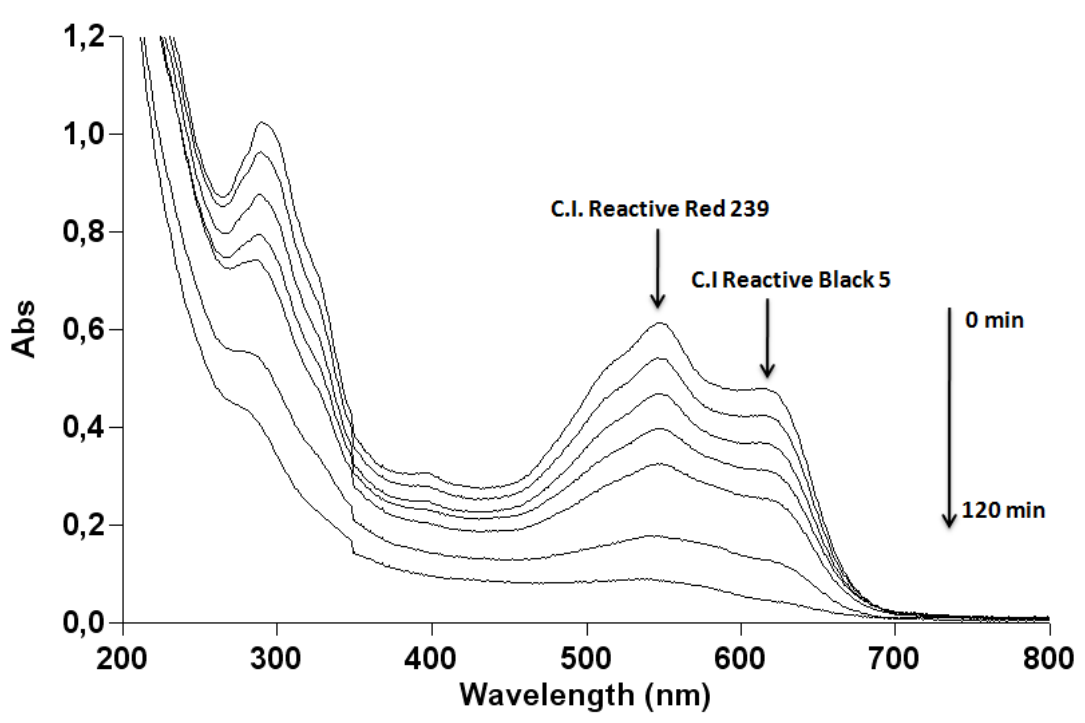


Figure 11. Effect of UV-Irradiation time on the degradation of a $30 \mathrm{mg} \cdot \mathrm{L}^{-1}$ mixture of the azo dyes C.I. Reactive Red $239(\bullet-)$ and C.I Reactive Black $5(-\square)$ with (a) $0.1 \mathrm{~g} \cdot \mathrm{L}^{-1}$ and (b) $1 \mathrm{~g} \cdot \mathrm{L}^{-1}$ of $\mathrm{TiO}_{2}$ and $2.60 \mathrm{~mW} / \mathrm{cm}^{2}$ of irradiation power by a $125 \mathrm{~W}$ mercury lamp.

(a)

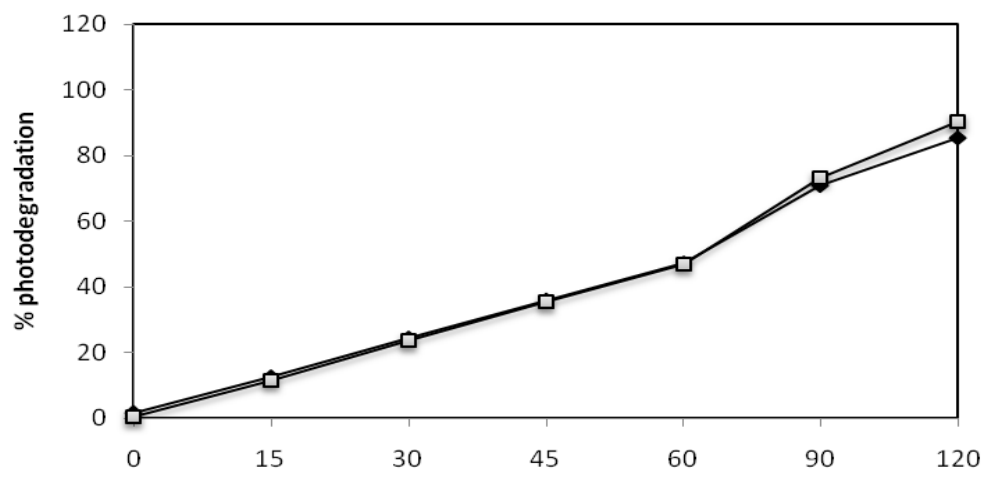

(b)

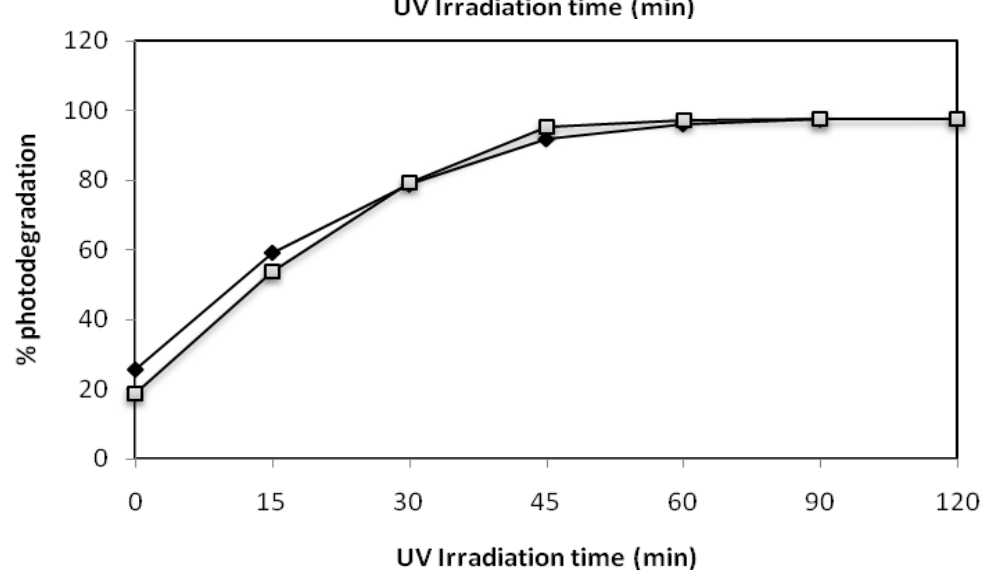

The photocatalytic degradation of the mixture of the two azo dyes was very satisfactory. C.I Reactive Red 239 was degraded $96 \%$ with $1 \mathrm{~g} \cdot \mathrm{L}^{-1}$ of $\mathrm{TiO}_{2}$ after $120 \mathrm{~min}$ of irradiation and when in the presence of C.I Reactive Black 5 in solution; the same results (97\% degradation) have been observed when the dye in solution was irradiated alone in the same conditions. When using $0.1 \mathrm{~g} \cdot \mathrm{L}^{-1}$ of $\mathrm{TiO}_{2}$ the degradation observed is also similar after $120 \mathrm{~min}$ of irradiation either for monocomponent solutions or bi-component solutions. C.I Reactive Black 5 achieved a similar degradation for both concentrations of $\mathrm{TiO}_{2}$ in monocomponent solutions and bi-component solutions. The simultaneous presence of the two azo dyes in solution did not disturb the photocatalytic degradation of each of them. The degradation rates achieved in mono and bi-component system were identical. These results obtained for azo dyes suggest that $\mathrm{TiO}_{2}$ can be efficiently used in complex systems containing more than one organic molecule to be degraded, because $\mathrm{TiO}_{2}$ is a powerful oxidizing agent and enables a nonspecific attack to organic compounds, as Bergamini et al. demonstrated [22].

\section{Experimental}

\subsection{Reagents and Materials}

Marine Remazol RGB 150\% gran (C.I Reactive Black 5, M.W. = 981.82 g/mol), Ultra Red Remazol gran (C.I. Reactive Red 239, M.W. = $1085.84 \mathrm{~g} / \mathrm{mol}$ ) textile dyes were obtained from DyStar (Brazil). The chemical structure of the dyes is shown in Figure 10. These compounds were used as 
received from the supplier without any further purification. The photocatalyst used was titanium dioxide, Degussa P25, which consists of $75 \%$ anatase and $25 \%$ rutile with a specific BET - surface area of $50 \mathrm{~m}^{2} \cdot \mathrm{g}^{-1}$ and a primary particle size of $20 \mathrm{~nm}$. The other chemicals used in this study such $\mathrm{NaOH}, \mathrm{HCl}$ and $\mathrm{H}_{2} \mathrm{O}_{2}$ were obtained from Merck. Water used to prepare dye solutions was MiliQwater.

Figure 12. Chemical structure of commercial azo dyes: (a) Marine Remazol RGB 150\% gran (C.I Reactive Black 5). (b) Ultra Red Remazol gran (C.I. Reactive Red 239).

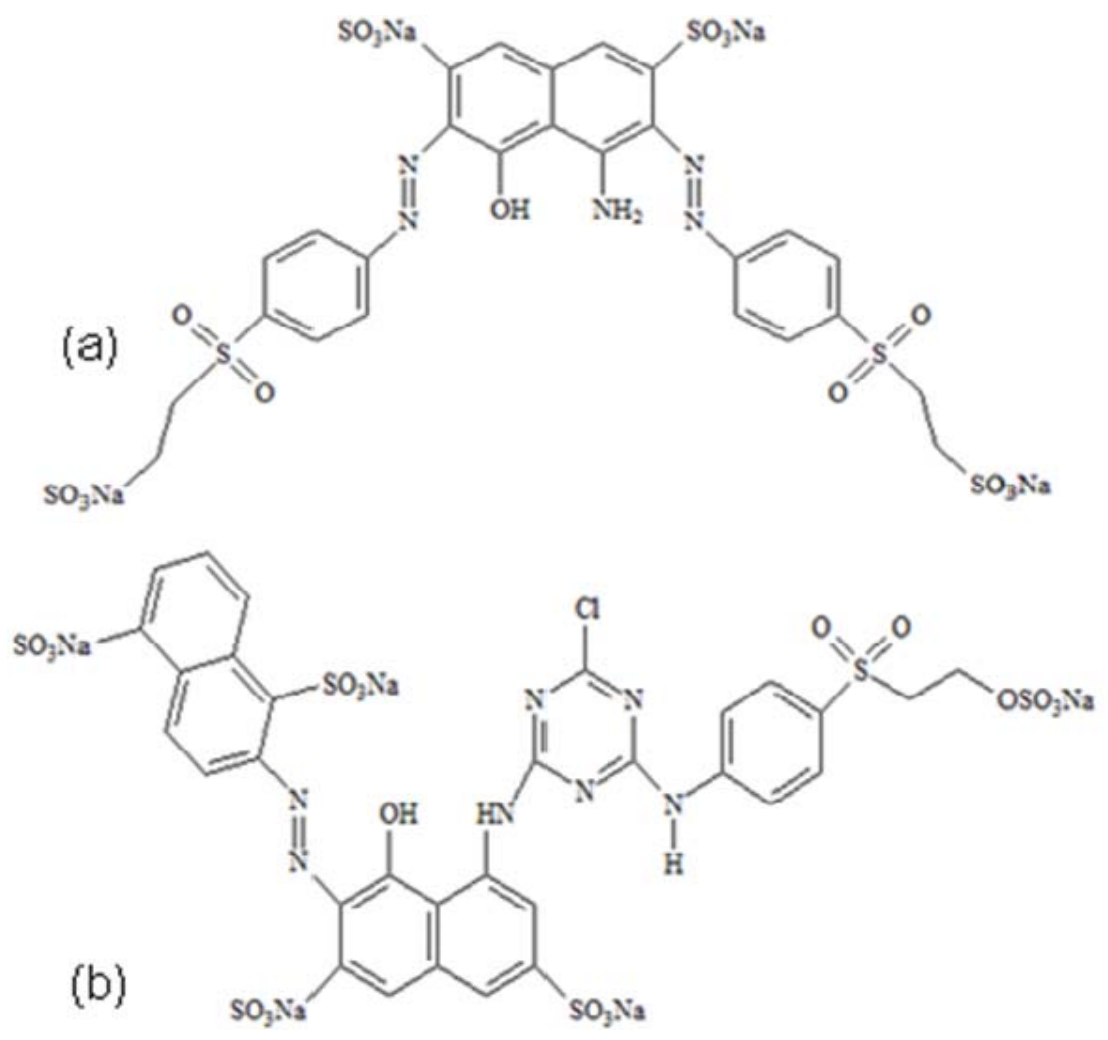

\subsection{Experiments Procedure}

Fresh solutions of the dyes were always prepared just before use and diluted according to the requirements of the experiments. The photodegradation cell was feed with $100 \mathrm{~mL}$ of the solution with stirring. Before irradiation, each sample was kept in the dark for $40 \mathrm{~min}$. During irradiation, continuous stirring was maintained to keep the suspension homogenous. Samples (ca. $3 \mathrm{~mL}$ ) were withdrawn at specific times $(0,15,30,45,60,90$ and $120 \mathrm{~min})$ for UV-Vis analysis and centrifuged for 10 minutes at $1,000 \mathrm{rpm}$. The concentration of the azo dyes in each sample was evaluated spectrophotometrically measuring the UV-Visible absorption at the maximum absorption wavelength of each dye (C.I Reactive Black 5; $\lambda_{\max }=615 \mathrm{~nm}$; C.I. Reactive Red 239; $\lambda_{\max }=540 \mathrm{~nm}$ ) and comparing it with the dye concentration calibration curve of each of the azo dyes used.

The samples were irradiated with a 125 Watts mercury vapour lamp (HQL 125 watts, from Osram). In this type of commercial lamps, the filament is protected by a glass bulb that cuts all UV-A and UV-B radiation. The glass bulb presents a white colour due to the internal phosphor coating that improves the radiation of the lamp on the visible region. This type of lamps with glass bulb is appropriated to selectively illuminate and exclusively excite $\mathrm{TiO}_{2}$ band gap, avoiding direct photolysis 
of the dye molecules that could be simultaneously promoted if all the lamp emission profile was available. The photoreactor is composed of an elliptical cover that supports the irradiation source described above and of a base containing a magnetic stirrer, where the samples to be irradiated are placed in $100 \mathrm{~mL}$ beakers. The light emitted from the mercury lamp was measured at $366 \mathrm{~nm}$ (the wavelength of $\mathrm{TiO}_{2}$ bandgap [47]) with the help of a Cole Parmer radiometer (series 9811-50) placed above the beaker with the sample to be irradiated. All samples were illuminated with an irradiation power of $2.6 \pm 0.2 \mathrm{~mW} / \mathrm{cm}^{2}$.

\subsection{Effect of $\mathrm{TiO}_{2}$ Photocatalyst Concentration}

A $30 \mathrm{mg} \cdot \mathrm{L}^{-1}$ dye solution of each azo dye $(100 \mathrm{~mL})$ containing different concentrations of $\mathrm{TiO}_{2}(0$, $1 \times 10^{-3}, 5 \times 10^{-3}, 1 \times 10^{-2}, 1 \times 10^{-1}$ and $1 \mathrm{~g} \cdot \mathrm{L}^{-1}$ ) were irradiated in the photoreactor described above for $120 \mathrm{~min}$.

\subsection{Effect of $p H$}

A solution of $30 \mathrm{mg} \cdot \mathrm{L}^{-1}$ C.I Reactive Black 5 and $0.1 \mathrm{~g} \cdot \mathrm{L}^{-1}$ of $\mathrm{TiO}_{2}(100 \mathrm{~mL})$ was used to degrade the azo dye solution at different $\mathrm{pH}$ values, which were adjusted by addition of $\mathrm{HCl}$ and $\mathrm{NaOH}$. Irradiation in the photoreactor described above was carried out for $60 \mathrm{~min}$.

\subsection{Recycling of $\mathrm{TiO}_{2}$}

The recycling of the photocatalyst was performed as follows: after a first photodegradation cycle of a $30 \mathrm{mg} \cdot \mathrm{L}^{-1}$ solution of C.I. Reactive Red $239(100 \mathrm{~mL})$ using $0.1 \mathrm{~g} \cdot \mathrm{L}^{-1}$ of $\mathrm{TiO}_{2}$ and $60 \mathrm{~min}$ irradiation, the treated solution of the dye was centrifuged with a rotation of 4,000 rpm for 15 minutes to remove $\mathrm{TiO}_{2}$. The liquid phase was filtered by a vacuum system with a Millipore membrane $(0.45 \mu \mathrm{m})$ and the solid phase containing the photocatalyst was carefully separated for reuse. After allowing it to dry in a desiccator with silica gel, the separated catalyst was added again to a new identical batch of C.I. Reactive Red 239 to be remediated. The process was repeated 5 times.

\subsection{Effect of Dye Concentration}

Different concentrations of each azo dye solutions $\left(30,50,80,100,120\right.$ and $\left.150 \mathrm{mg} \cdot \mathrm{L}^{-1}, 100 \mathrm{~mL}\right)$ containing $0.1 \mathrm{~g} \cdot \mathrm{L}^{-1}$ of $\mathrm{TiO}_{2}$ were illuminated in the photoreactor for $120 \mathrm{~min}$.

\subsection{Effect of $\mathrm{H}_{2} \mathrm{O}_{2}$}

Thirty $\mathrm{mg} \cdot \mathrm{L}^{-1}$ dye solution of each azo dye $(100 \mathrm{~mL})$ containing $0.1 \mathrm{~g} \cdot \mathrm{L}^{-1}$ of $\mathrm{TiO}_{2}$ and different concentrations of hydrogen peroxide $\left(0,3 \times 10^{-3}, 6 \times 10^{-3}, 9 \times 10^{-3}, 1.2 \times 10^{-2}, 3 \times 10^{-2}\right.$ and $6 \times 10^{-2} \mathrm{~mol} \cdot \mathrm{L}^{-1}$ ) were illuminated in the photoreactor for $60 \mathrm{~min}$.

\subsection{Effect of the Mixture of the Two Azo Dyes}

Thirty $\mathrm{mg} \cdot \mathrm{L}^{-1}$ dye solutions of each azo dye under study $(50 \mathrm{~mL})$ were added in a beaker in order to have a $100 \mathrm{~mL}$ mixed solution of the two azo dyes. The photodegradation of the mixture of the two 
azo dyes was tested with two different concentrations of $\mathrm{TiO}_{2}\left(1 \mathrm{~g} \cdot \mathrm{L}^{-1}\right.$ and $\left.0.1 \mathrm{~g} \cdot \mathrm{L}^{-1}\right)$ and were irradiated in the photoreactor described above for $120 \mathrm{~min}$.

\subsection{Equipment}

A double beam UV-Visible spectrophotometer (Shimadzu UV-1601PC) was used for the spectrophotometric determination of azo dyes absorption spectra from 200-900 nm. Spectra of the dyes in water were recorded with the help of $1 \mathrm{~cm}$ quartz cuvettes.

\section{Conclusions}

The photocatalytic degradation of two commercial azo dyes mediated by $\mathrm{TiO}_{2}$ was successfully achieved. Results indicated that the photocatalytic degradation of two dyes in water with powdered $\mathrm{TiO}_{2}$ depended on the concentration of dye, amount of photocatalyst used, UV-irradiation time, solution $\mathrm{pH}$ and concentration of added hydrogen peroxide. It was found that the optimal amount of catalyst to be used was $0.1 \mathrm{~g} \mathrm{~L}^{-1}$. Concerning the initial dye concentration, it has been observed that the increase in the initial dye concentration leaded to a decrease in photodegradation. The photodegradation is favored in acidic solution. The optimal $\mathrm{H}_{2} \mathrm{O}_{2}$ concentration to be added was found to be $3 \times 10^{-3} \mathrm{~mol} \cdot \mathrm{L}^{-1}$. The recycling of $\mathrm{TiO}_{2}$ can be performed with the photocatalyst being able to be adequately used in other reactions. The $\mathrm{TiO}_{2}$ has the same photocatalytic activity in reactions with monocomponent solutions and bi-component solutions.

\section{Acknowledgements}

The authors gratefully acknowledge Fundação para a Ciência e Tecnologia (FCT, Portugal) through projects PTDC|QUI|65510\2006 and PTDC|QUI|70153\2006 and DyStar Brazil for the gift of the azo dyes. E.M. Saggioro thanks Faperj and ENSP/FioCruz for Master grants. J.C. Moreira thanks Faperj and CNPq.

\section{References and Notes}

1. Chen, C.; Wang, Z.; Ruan, S.; Zou, B.; Zhao, M.; Wu, F. Photocatalytic degradation of C.I. Acid Orange 52 in the presence of $\mathrm{Zn}$-doped $\mathrm{TiO}_{2}$ prepared by a stearic acid gel method. Dyes Pigm. 2008, 77, 204-209.

2. Vautier, M.; Guillard, C.; Herrmann, J. Photocatalytic Degradation of Dyes in Water: Case Study of Indigo and of Indigo Carmine. J. Catal. 2001, 201, 46-59.

3. Wang, C.; Lee, C.; Lyu, M.; Juang, L. Photocatalytic degradation of C.I. Basic Violet 10 using $\mathrm{TiO}_{2}$ catalysts supported by $\mathrm{Y}$ zeolite: An investigation of the effects of operational parameters. Dyes Pigm. 2008, 76, 817-824.

4. Zainal, Z.; Hui, L.K.; Hussein, M.Z.; Taufiq-Yap, Y.H.; Abdullah, A.H.; Ramli, I. Removal of dyes using immobilized titanium dioxide illuminated by fluorescent lamps. J. Hazard. Mater. 2005, 125, 113-120. 
5. Behnajady, M.A.; Modirshahla, N.; Daneshvar, N.; Rabbani, M. Photocatalytic degradation of an azo dye in a tubular continuous-flow photoreactor with immobilized $\mathrm{TiO}_{2}$ on glass plates. Chem. Eng. J. 2007, 127, 167-176.

6. Robinson, T.; McMullan, G.; Marchant, R.; Nigam, P. Remediation of dyes in textile effluent: A critical review on current treatment technologies with a proposed alternative. Bioresour. Technol. 2001, 77, 247-255.

7. Habibi, M.H.; Hassanzadeh, A.; Mahdavi, S. The effect of operational parameters on the photocatalytic degradation of three textile azo dyes in aqueous $\mathrm{TiO}_{2}$ suspensions. J. Photochem. Photobiol. A Chem. 2005, 172, 89-96.

8. Bizani, E.; Fytianos, K.; Poulios, I.; Tsiridis, V. Photocatalytic decolorization and degradation of dye solutions and wastewaters in the presence of titanium dioxide. J. Hazard. Mater. 2006, 136, 85-94.

9. Chen, C.; Lu, C.; Chung, Y. Photocatalytic degradation of ethyl violet in aqueous solution mediated by $\mathrm{TiO}_{2}$ suspensions. J. Photochem. Photobiol. A Chem. 2006, 181, 120-125.

10. Oliveira, A.S.; Saggioro, E.M.; Barbosa, N.R.; Mazzei, A.; Ferreira, L.F.V.; Moreira, J.C. Surface Photocatalysis: A Study of the Thickness of $\mathrm{TiO}_{2}$ Layers on the Photocatalytic Decomposition of Soluble Indigo Blue Dye. Rev. Chim. (Bucharest, Rom.) 2011, 62, 462-468.

11. Sojić, D.; Despotović, V.; Abramović, B.; Todorova, N.; Giannakopoulou, T.; Trapalis, C. Photocatalytic Degradation of Mecoprop and Clopyralid in Aqueous Suspensions of Nanostructured N-doped $\mathrm{TiO}_{2}$. Molecules 2010, 15, 2994-3009.

12. Vasapollo, G.; Mele, G.; Sole, R.D.; Pio, I.; Li, J.; Mazzetto, S.E. Use of Novel CardanolPorphyrin Hybrids and Their $\mathrm{TiO}_{2}$-Based Composites for the Photodegradation of 4-Nitrophenol in Water. Molecules 2011, 16, 5769-5784.

13. Gouvêa, C.A.K.; Wypych, F.; Moraes, S.G.; Durán, N.; Nagata, N.; Peralta-Zamora, P. Semiconductor-assisted Photocatalytic Degradation of Reactive Dyes in Aqueous Solution. Chemosphere 2000, 40, 433-440.

14. Gonçalves, M.S.T.; Campos, A.M.F.O.; Pinto, E.M.M.S.; Plasencia, P.M.S.; Queiroz, M.J.R.P. Photochemical treatment of solutions of azo dyes containing $\mathrm{TiO}_{2}$. Chemosphere 1999, 39, 781-786.

15. Tariq, M.A.; Faisal, M.; Saquib, M.; Muneer, M. Heterogeneous photocatalytic degradation of an anthraquinone and a triphenylmethane dye derivative in aqueous suspensions of semiconductor. Dyes Pigm. 2008, 76, 358-365.

16. Saien, J.; Soleymani, A.R. Degradation and mineralization of Direct Blue 71 in a circulating upflow reactor by $\mathrm{UV} / \mathrm{TiO}_{2}$ process and employing a new method in kinetic study. J. Hazard. Mater. 2007, 144, 506-512.

17. Aarthi, T.; Narahari, P.; Madras, G. Photocatalytic degradation of Azure and Sudan dyes using nano $\mathrm{TiO}_{2}$. J. Hazard. Mater. 2007, 149, 725-734.

18. Saquib, M.; Abu Tariq, M.; Haque, M.M.; Muneer, M. Photocatalytic degradation of disperse blue 1 using $\mathrm{UV} / \mathrm{TiO}_{2} / \mathrm{H}_{2} \mathrm{O}_{2}$ process. J. Environ. Manage. 2008, 88, 300-306.

19. Huang, M.; Xu, C.; Wu, Z.; Huang, Y.; Lin, J.; Wu, J. Photocatalytic discolorization of methyl orange solution by $\mathrm{Pt}$ modified $\mathrm{TiO}_{2}$ loaded on natural zeolite. Dyes Pigm. 2008, 77, 327-334. 
20. Andronic, L.; Duta, A. $\mathrm{TiO}_{2}$ thin films for dyes photodegradation. Thin Solid Films 2007, 515, 6294-6297.

21. Liu, H.L.; Chiou, Y.R. Optimal decolorization efficiency of Reactive Red 239 by $\mathrm{UV} / \mathrm{TiO}_{2}$ photocatalytic process coupled with response surface methodology. Chem. Eng. J. 2005, 112, 173-179.

22. Bergamini, R.B.M.; Azevedo, E.B.; Araújo, L.R.R. Heterogeneous photocatalytic degradation of reactive dyes in aqueous $\mathrm{TiO}_{2}$ suspensions: Decolorization kinetics. Chem. Eng. J. 2009, 149, 215-220.

23. Zielinska, B.; Grzechulska, J.; Grzmil, B.; Morawski, A.W. Photocatalytic degradation od Reactive Black 5 A comparison between $\mathrm{TiO}_{2}$-Tytanpol $\mathrm{A} 11$ and $\mathrm{TiO}_{2}$-Degussa $\mathrm{P} 25$ photocatalysts. Appl. Catal. B 2001, 35, L1-L7.

24. Alaton, I.A.; Balcioglu, I.A. Photochemical and Heterogeneous photocatalytic degradation of waste vinylsulphone dyes: A case study with hydrolysed Reactive Black 5. J. Photochem. Photobiol. A Chem. 2001, 141, 247-254.

25. Muruganandham, M.; Sobana, N.; Swaminathan, M. Solar assited photocatalytic and photochemical degradation of Reactive Black 5. J. Hazard. Mater. 2006, 137, 1371-1376.

26. Tang, C.; Chen, V. The photocatalytic degradation of reactive black 5 using $\mathrm{TiO}_{2} / \mathrm{UV}$ in an annular photoreactor. Water Res. 2004, 38, 2775-2781.

27. Saquib, M.; Munner, M. Photocatalytic degradation of two selected textile dye derivates, Eosine Yellowish and $\rho$-Rosaniline, aqueous suspensions of titanium dioxide. J. Environ. Sci. Health Part A Toxic/Hazard. Subst. Environ. Eng. 2003, 38, 2581-2598.

28. Fox, M.A.; Dulay, M.T. Heterogeneous Photocatalysis. Chem. Rev. 1993, 93, 341-357.

29. Konstantinou, I.K.; Albanis, T.A. $\mathrm{TiO}_{2}$-assisted photocatalytic degradation of azo dyes in aqueous solution: kinetic and mechanistic investigations: A review. Appl. Catal. B 2004, 49, 1-14.

30. Feng, W.; Nansheng, D.; Helin, H. Degradation mechanism of azo dye C.I. reactive red 2 by iron powder reduction and photooxidation in aqueous solutions. Chemosphere 2000, 41, 1233-1238.

31. Karkmaz, M.; Puzenat, E.; Guillard, C.; Herrmann, J.M. Photocatalytic degradation of the alimentary azo dye amaranth. Mineralization of the azo group to nitrogen. Appl. Catal. B 2004, 51, 183-194.

32. Mozia, S.; Tomaszewska, M.; Morawski, A.W. Photodegradation of azo dye Acid Red 18 in a quartz labyrinth flow reactor with immobilized $\mathrm{TiO}_{2}$ bed. Dyes Pigm. 2007, 75, 60-66.

33. Al-Ekabi, H.; Serpone, N. Photocatalytic degradation of chlorinated phenols in aerated aqueoussolutions over $\mathrm{TiO}_{2}$ supported on a glass matrix. J. Phys. Chem. 1988, 92, 5726-5731.

34. Wang, N.; Li, J.; Zhu, L.; Dong, Y.; Tang, H. Highly photocatalytic activity of metallic hydroxide/titanium dioxide nanoparticules prepared via a modified wet precipitation process. J. Photochem. Photobiol. A Chem. 2008, 198, 282-287.

35. Dostanic J.M.; Loncarevic D.R.; Bankovic P.T.; Cvetkovik O.G.; Jovanovic D.M.; Mijin D.Z. Influence of process parameters on the photodegradation of synthesized azo pyridine dye in $\mathrm{TiO}_{2}$ water suspension under simulated sunlight. J. Environ. Sci. Health Part A Toxic/Hazard. Subst. Environ. Eng. 2011, 46, 70-79.

36. Xie Y.; Yuan, C. Transparent $\mathrm{TiO}_{2}$ sol nanocrystallites mediated homogeneous-like photocatalytic reaction and hydrosol recycling process. J. Mater. Sci. 2005, 40, 6375-6383. 
37. Han, F.; Kambala, V.S.R.; Srinivasan, M. Tailored titanium dioxide photocatalysts for the degradation of organic dyes in wastewater treatment: A review. Appl. Catal. A 2009, 359, 25-40.

38. Muruganandham, M.; Swaminathan, M. Photocatalytic decolourisation and degradation of Reactive Orange 4 by $\mathrm{TiO}_{2}$-UV process. Dyes Pigm. 2006, 68, 133-142.

39. Daneshvar, N.; Salari, D.; Khataee, A.R. Photocatalytic degradation of azo dye acid red 14 in water: investigation of the effect of operational parameters. J. Photochem. Photobiol. A Chem. 2003, 157, 111-116.

40. Grzechulska, J.; Morawski, A.W. Photocatalytic decomposition of azo-dye acid black 1 in water over modified titanium dioxide. Appl. Catal. B 2002, 36, 45-51.

41. Carter, S.R.; Stefan, M.I.; Bolton, J.R.; Safarzadeh-Amiri, A. UV/ $\mathrm{H}_{2} \mathrm{O}_{2}$ Treatment of methyl tertbutyl ether in contaminated waters. Environ. Sci. Technol. 2000, 34, 659-662.

42. Malato, S.; Blanco, J.; Ritchter, C.; Braun, B.; Maldonado, M.I. Enhancement of the rate of solar photocatalytic mineralization of organic pollutants by inorganic oxidizing species. Appl. Catal. B 1998, 17, 347-356.

43. Mahmoodi, N.M.; Arami, M.; Limaee, N.Y.; Gharanjig, K.; Ardejani, F.D. Decolorization and mineralization of textile dyes at solution bulk by heterogeneous nanophotocatalysis using immobilized nanoparticles of titanium dioxide. Colloids Surf. A 2006, 290, 125-131.

44. Prado, A.G.S.; Bolzon, L.B.; Pedroso, C.P.; Moura, A.O.; Costa, L.L. $\mathrm{Nb}_{2} \mathrm{O}_{5}$ as efficient and recyclable photocatalyst for indigo carmine degradation. Appl. Catal. A 2008, 82, 219-224.

45. Aguedacha, A.; Brosillonb, S.; Morvanb, J.; Lhadi, E.K. Photocatalytic degradation of azo-dyes reactive black 5 and reactive yellow 145 in water over a newly deposited titanium dioxide. Appl. Catal. B 2005, 57, 55-62.

46. Zhu, C.; Wang, L.; Kong, L.; Yang, X.; Wang, L.; Zheng, S.; Chen, F.; Maizhi, F.; Zong, H. Photocatalytic degradation of AZO dyes by supported $\mathrm{TiO}_{2} / \mathrm{UV}$ in aqueous solution. Chemosphere 2000, 41, 303-309.

47. Hachem, C.; Bocquillon, F.; Zahraa, O.; Bouchy, M. Decolourization of textile industry wastewater by the photocatalytic degradation process. Dyes Pigm. 2001, 49, 117-125.

Sample Availability: Samples of the compounds are available from the authors.

(C) 2011 by the authors; licensee MDPI, Basel, Switzerland. This article is an open access article distributed under the terms and conditions of the Creative Commons Attribution license (http://creativecommons.org/licenses/by/3.0/). 